anticonvulsants and barbiturates is uncertain. Possibly a skeleton damaged by pretransplant uraemia is unusually susceptible to changes in vitamin D metabolism, and changes in liver function produced by immunosuppressive drugs may play a part.

In non-uraemic epileptic patients treated with phenobarbitone and phenytoin there is an increased turnover of 25-hydroxycholecalciferol with the production of more polar, biologically inactive metabolites that are excreted in the bile at an accelerated rate. ${ }^{1314}$ This is attributed to drug-induced enhancement of hepatic microsomal enzyme activity. ${ }^{13-15}$ A similar increased turnover of vitamin $\mathrm{D}$ occurs in uraemia. ${ }^{16}$ This may well result from an increase in hepatic microsomal activity, which has been found in uraemic patients. ${ }^{17}$ Wake and Maddocks ${ }^{17}$ have also shown that in uraemic patients hepatic enzymes may be further induced by phenobarbitone by mouth, so that it would not be surprising if anticonvulsants accentuated this abnormality of vitamin D metabolism. In 1974 we suggested a possible aetiological role for enzyme-inducing drugs in the osteomalacia of transplanted patients. "This form of osteomalacia is to some extent resistant to vitamin $\mathrm{D}$. In three of the cases reported here large doses of calciferol (50000 units daily) were required to effect recovery.

Awareness of the risk of osteomalacia when enzyme-inducing drugs such as phenytoin and phenobarbitone are given in uraemia and after renal transplantation should lead to more cautious use of these drugs and their earlier withdrawal. When their continued use is essential in patients who have had transplants prophylactic treatment with large vitamin D supplements is probably advisable. We have not succeeded in healing osteomalacia in patients on regular dialysis taking enzymeinducing drugs with calciferol and dihydrotachysterol, and their condition is also relatively resistant to 1-alpha-hydroxycholecal- ciferol. Consequently sedatives and other drugs known to induce hepatic enzymes should be avoided so far as possible during regular haemodialysis.

We acknowledge the help of Mrs J Little, computer secretary, and Mr R A McNay, statistician, Northern Regional Health Authority, with the analysis of data on the patients on regular haemodialysis, and also the help given by the department of biochemistry at the Royal Victoria Infirmary.

Dr A M Pierides and Miss K M Peart are supported by MRC grant No G/973/693/C.

\section{References}

${ }^{1}$ Siddiqui, J, and Kerr, D N S, British Medical Bulletin, 1971, 27, 153.

2 Simpson, W, et al, British fournal of Radiology, In press.

${ }^{3}$ Siddiqui, J, et al, Procesdings of the European Dialysis and Transplant Association, 1971, 8, 149.

${ }^{4}$ Dent, C E, et al, British Medical fournal, 1970, 4, 69.

${ }^{5}$ Richens, A, and Rowe, D J F, British Medical fournal, 1970, 4, 73.

${ }^{6}$ Carroll, R N P, et al, Proceedings of the European Diaylsis and Transplant Association, 1973, 10, 446.

'Pierides, A M, et al, Proceedings of the European Dialysis and Transplant Association, 1974, 11, 481.

${ }^{8}$ Ellis, H A, and Peart, K M, fournal of Clinical Pathology, 1973, 26, 83.

${ }^{9}$ Willis, J B, Spectrochimica Acta, 1960, 16, 259.

10 Bowers, N G, and McComb, R B, Clinical Chemistry, 1966, 12, 1970.

${ }^{11}$ Whitfield, J B, et al, British Medical fournal, 1973, 1, 316.

12 Hill, A V L, et al, in Proceedings of Stcond Workshop on Vitamin D, Wiesbaden, 1974, ed A W Norman, et al, p 643. New York, de Gruyter, 1975.

${ }^{13}$ Hahn, T J, et al, fournal of Clinical Invostigation, 1972, 51, 741.

${ }^{14} \mathrm{Jubiz}, \mathrm{W}$, et al, New England fournal of Medicine, 1970, 283, 11.

15 Hunter, J, et al, British Medical fournal, 1971, 4, 202.

${ }^{16}$ Avioli, L V, at al, fournal of Clinical Investigation, 1968, 47, 2239.

17 Wake, C J, and Maddocks, J L, Lancet, 1975, 1, 516.

\title{
Plasma prednisolone levels after administration of prednisolone-2I-phosphate as a retention enema in colitis
}

\author{
J POWELL-TUCK, J E LENNARD-JONES, C S MAY, C G WILSON, J W PATERSON
}

British Medical fournal, 1976, 1, 193-195

\section{Summary}

A competitive protein-binding assay was used to measure plasma prednisolone levels after administration of prednisolone-21-phosphate retention enemas to seven patients with colitis. Prednisolone appeared in the plasma of all patients after the enema, and concentrations rose to a peak within three hours. In five of the patients plasma prednisolone levels were also measured after the same dose of prednisolone by mouth. Although in individual patients the plasma levels achieved by enema

\section{St Mark's Hospital, London EC}

J POWELL-TUCK, MB, MRCP, medical registrar

J E LENNARD-JONES, MD, FRCP, consultant gastroenterologist

Asthma Research Council Clinical Pharmacology Unit, Cardiothoracic Institute, Brompton Hospital, London SW3

C S MAY, MB, FRACP, clinical lecturer (present address: Department of Medicine, University of Aberdeen, Aberdeen AB9 2ZD)

C G WILSON, PHD, lecturer (present address: Department of Physiology and Pharmacology, University Hospital and Medical School, Nottingham NG7 2UH)

$\mathrm{J}$ W PATERSON, MB, MRCP, reader in clinical pharmacology (now professor of clinical pharmacology, University of Western Australia, Perth) were often quite different from those achieved by mouth, overall the levels achieved by each mode of administration were of a similar order. These findings suggest that $20 \mathrm{mg}$ prednisolone given by retention enema may well exert a systemic effect.

\section{Introduction}

Prednisolone-21-phosphate administered as a retention enema is valuable in treating colitis ${ }^{1}$ but there is doubt about how much prednisolone is absorbed from such enemas. Since it has hitherto been impossible to measure small quantities of prednisolone in blood samples observations on the absorption of prednisolone from the rectum have been indirect. Recent advances in the measurement of prednisolone by competitive protein binding ${ }^{2}$ and by radioimmunoassay ${ }^{3}$ have allowed nanogram quantities of the steroid to be measured directly in plasma. We describe here the use of a competitive protein-binding method to measure the amount of prednisolone absorbed from the rectum. We compared the levels observed after an oral dose of prednisolone with those after an equivalent dose given by retention enema in the same patient.

\section{Patients and methods}

Prednisolone was measured in 2-ml plasma samples using a competitive protein-binding assay ${ }^{2}$ modified as described by Wilson 
et al. ${ }^{4}$ Plasma samples were extracted after addition of $6,7(n)-{ }^{3} \mathrm{H}-$ prednisolone $(2 \mathrm{nCi})$. Prednisolone and cortisol were separated by thin-layer chromatography on silica gel plates and the prednisolone was located using a radiochromatograph spark chamber (Birchover Instruments, Letchworth, Herts). The recovery of the prednisolone from the plasma samples after chromatography was calculated from the loss of ${ }^{3} \mathrm{H}$-prednisolone marker. The purified prednisolone was then measured by the competitive protein binding method of Pegg and Keane ${ }^{5}$ by equilibration with ${ }^{3} \mathrm{H}$-prednisolone bound to transcortin. The unbound steroid was then adsorbed on to dextran $T_{70}$-coated charcoal, the samples centrifuged, and the ${ }^{3} \mathrm{H}$ in the supernatant phase measured by liquid scintillation counting. A standard curve of $\%$ total bound ${ }^{3} \mathrm{H}$ prednisolone was constructed and the prednisolone concentration of the sample read off.

Seven patients, six with ulcerative colitis and one with Crohn's disease affecting the rectosigmoid, were studied. Each patient gave his informed consent to the study. Patients received no prednisolone other than the experimental doses during the study and 12 hours before. The extent of the colitis was assessed radiologically and the severity of the mucosal inflammation was judged by sigmoidoscopy. ${ }^{6}$ ? The distance travelled by a therapeutic enema of $100 \mathrm{ml}$ was assessed radiologically before or after the study. ${ }^{7}$

On one day blood samples were taken at intervals during the eight hours after administration of $20 \mathrm{mg}$ prednisolone (as prednisolone21 -phosphate) in tap water $(100 \mathrm{ml})$ as a retention enema. On another day blood samples were taken over the same period after oral administration of $20 \mathrm{mg}$ of prednisolone in one dose to the fasting subjects. The time of blood sampling after the administration of the prednisolone was noted, and the plasma was immediately separated and stored at $-30^{\circ} \mathrm{C}$ until assayed.

\section{Results}

Table I shows the clinical details of the patients, and the results after oral and rectal administration are shown in table II. No prednisolone was detected in blood samples taken immediately before administration of the enema or tablets. After administration of the retention enema prednisolone appeared in the blood in all patients and the plasma prednisolone level rose to a peak within three hours. In cases 4 and 7

TABLE I-Clinical details of patients in plasma prednisolone study

\begin{tabular}{|c|c|c|c|c|c|}
\hline $\begin{array}{c}\text { Case } \\
\text { No }\end{array}$ & $\begin{array}{l}\text { Age } \\
\text { and } \\
\text { sex }\end{array}$ & $\begin{array}{l}\text { Extent of } \\
\text { disease }\end{array}$ & $\begin{array}{c}\text { Distance } \\
\text { travelled } \\
\text { by enema }\end{array}$ & $\begin{array}{l}\text { Sigmoidoscopic } \\
\text { appearances }\end{array}$ & $\begin{array}{l}\text { Time } \\
\text { enema } \\
\text { retained } \\
\text { (hours) }\end{array}$ \\
\hline $\begin{array}{l}1 \\
2 \\
3 \\
4 \\
5 \\
6 \\
7\end{array}$ & $\begin{array}{ll}56 & \mathrm{M} \\
34 & \mathrm{~F} \\
71 & \mathrm{~F} \\
68 & \mathrm{M} \\
27 & \mathrm{M} \\
77 & \mathrm{~F} \\
61 & \mathrm{M}\end{array}$ & $\begin{array}{l}\text { Proctosigmoiditis } \\
\text { Proctosigmoiditis } \\
\text { Substantial* } \\
\text { Proctosigmoiditis } \\
\text { Extensive } \dagger \\
\text { Proctosigmoiditis } \\
\text { Left-sided } \ddagger\end{array}$ & $\begin{array}{l}\text { Splenic flexure } \\
\text { Mid-sigmoid } \\
\text { Mid-transverse } \\
\text { Mid-sigmoid } \\
\text { ? } \\
\text { Sigmoid } \\
\text { Splenic flexure }\end{array}$ & $\begin{array}{l}\text { Normal } \\
\text { Moderately active } \\
\text { Inactive } \\
\text { Active } \\
\text { Inactive } \\
\text { Moderately active } \\
\text { Active }\end{array}$ & $\begin{array}{r}>6 \\
3 \\
>3 \\
1.6 \\
>2.5 \\
>3 \\
0.6\end{array}$ \\
\hline
\end{tabular}

* Substantial $=$ Distal to hepatic flexure.

†xtensive $=$ Involving colon proximal to hepatic flexure.

tLeft-sided $=$ Distal to splenic flexure.

TABLE II-Plasma prednisolone levels after administration of $20 \mathrm{mg}$ orally and rectally in seven patients

\begin{tabular}{|c|c|c|c|c|c|c|c|c|c|c|c|c|}
\hline \multirow{2}{*}{$\begin{array}{l}\text { Case } \\
\text { No }\end{array}$} & \multirow{2}{*}{$\begin{array}{l}\text { Mode of } \\
\text { administration }\end{array}$} & \multicolumn{11}{|c|}{$\begin{array}{l}\text { Plasma prednisolone levels (nmol/l) } \\
\text { hours after administration* }\end{array}$} \\
\hline & & 0.5 & 1.0 & 1.5 & $2 \cdot 0$ & $2 \cdot 5$ & 3.0 & $4 \cdot 0$ & $5 \cdot 0$ & 6.0 & $7 \cdot 0$ & 8.0 \\
\hline 1 & $\begin{array}{l}\text { Rectal } \\
\text { Oral }\end{array}$ & 452 & 932 & $\begin{array}{l}186 \\
971\end{array}$ & $\begin{array}{l}250 \\
843\end{array}$ & 264 & 203 & $\begin{array}{l}175 \\
807\end{array}$ & $\begin{array}{l}225 \\
591\end{array}$ & $\begin{array}{r}72 \\
447 \\
\end{array}$ & $\begin{array}{r}28 \\
438\end{array}$ & 380 \\
\hline 2 & $\begin{array}{l}\text { Rectal } \\
\text { Oral }\end{array}$ & & $\begin{array}{l}269 \\
363\end{array}$ & \begin{tabular}{|l|}
241 \\
657
\end{tabular} & $\begin{array}{l}322 \\
696\end{array}$ & 289 & $\begin{array}{l}366 \\
594\end{array}$ & $\begin{array}{l}336 \\
716\end{array}$ & \begin{tabular}{|l|}
241 \\
682
\end{tabular} \mid & \begin{tabular}{|l|}
244 \\
632
\end{tabular} & $\begin{array}{l}208 \\
530\end{array}$ & 158 \\
\hline 3 & $\begin{array}{l}\text { Rectal } \\
\text { Oral }\end{array}$ & $\begin{array}{l}461 \\
555\end{array}$ & 302 & $\begin{array}{l}341 \\
391\end{array}$ & $\begin{array}{l}469 \\
377\end{array}$ & $\begin{array}{l}447 \\
322\end{array}$ & $\begin{array}{l}394 \\
252\end{array}$ & $\begin{array}{l}302 \\
230\end{array}$ & $\begin{array}{l}216 \\
166\end{array}$ & $\begin{array}{l}144 \\
155\end{array}$ & $\begin{array}{r}0 \\
122\end{array}$ & $\begin{aligned} 0 \\
111\end{aligned}$ \\
\hline 4 & $\begin{array}{l}\text { Rectal } \\
\text { Oral }\end{array}$ & $\begin{array}{l}233 \\
730\end{array}$ & $\begin{array}{r}191 \\
1207\end{array}$ & 361 & 203 & $\begin{array}{r}158 \\
1151\end{array}$ & \begin{tabular}{|l|}
119 \\
932
\end{tabular} & $\begin{array}{r}105 \\
1135\end{array}$ & $\begin{array}{r}86 \\
816\end{array}$ & 882 & 599 & 571 \\
\hline 5 & $\begin{array}{l}\text { Rectal } \\
\text { Oral }\end{array}$ & $\begin{array}{l}427 \\
275\end{array}$ & $\begin{array}{l}560 \\
239\end{array}$ & $\begin{array}{l}860 \\
228\end{array}$ & $\begin{array}{l}810 \\
219\end{array}$ & $\begin{array}{l}638 \\
252\end{array}$ & $\begin{array}{l}613 \\
186\end{array}$ & $\begin{array}{l}538 \\
258\end{array}$ & \begin{tabular}{|l|}
383 \\
136
\end{tabular} & $\begin{array}{r}272 \\
83\end{array}$ & $\begin{array}{r}166 \\
83\end{array}$ & \\
\hline 6 & Rectal & & & 39 & & 333 & 130 & 19 & 11 & 89 & & 83 \\
\hline 7 & Rectal & 344 & 275 & 0 & 42 & & 0 & 0 & 0 & 0 & 0 & \\
\hline
\end{tabular}

*Prednisolone was estimated at slightly different times in each patient, but all results have been grouped under intervals corrected to the nearest half hour.

Conversion: SI to traditional units-Prednisolone: $1 \mathrm{nmol} / 1 \approx 0.36 \mathrm{ng} / \mathrm{ml}$.

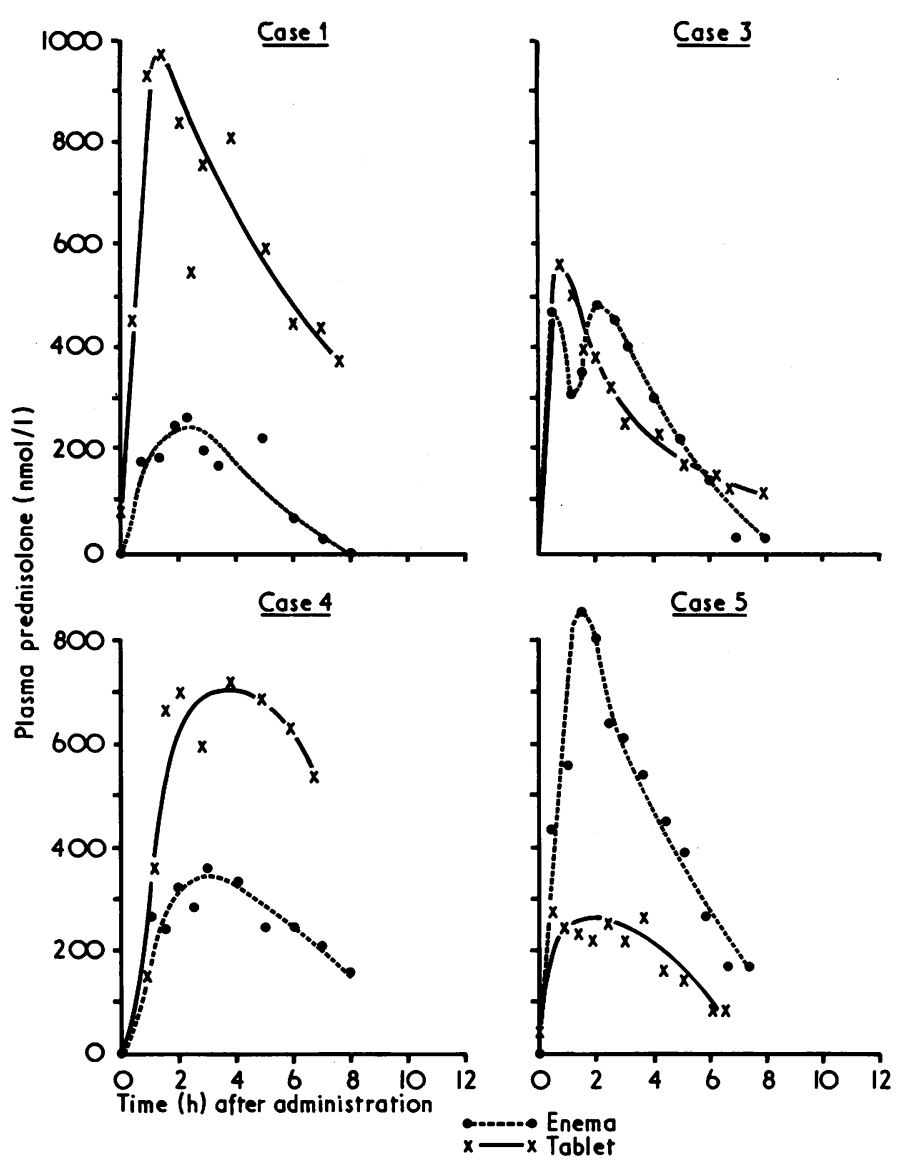

Plasma prednisolone concentrations in four patients after oral and rectal administration of $20 \mathrm{mg}$.

Conversion: SI to traditional units-Prednisolone:

the enema was retained for only 0.6 and 1.6 hours respectively and the peak tended to occur earlier and the levels fell after evacuation. Concentrations in the remaining patients varied widely and there was no obvious correlation with the activity of the disease or the distance travelled by the enema. The comparisons between the plasma prednisolone levels after oral and rectal administration for the four patients who retained the enema (see fig) show that in two patients the levels were higher after oral administration, in one the levels were higher after the enema, and in one they were similar.

\section{Discussion}

The method used for measuring prednisolone is time consuming but has the advantage of measuring prednisolone specifically in the presence of cortisol or other steroids. It can measure levels above $56 \mathrm{nmol} / \mathrm{l}(20 \mathrm{ng} / \mathrm{ml})$, and when reproducibility is checked there is a variation in duplicate samples of less than $10 \%{ }^{4}$ The plasma prednisolone levels observed after an enema were much the same as those observed after an equivalent dose of prednisolone taken by mouth, both in these patients and in 26 others without gastrointestinal disease studied after an oral dose. ${ }^{8}$ The individual levels observed in any patient may vary considerably, however: in two of our patients the levels after enema were less than those after oral administration; in one the levels were greater than after oral administration; and in one the levels were similar.

There has been some controversy about the absorption of prednisolone from retention enemas. At least two studies have shown evidence of some adrenal suppression ${ }^{9} 10$ but another showed none. ${ }^{11}$ Wood et $a l^{12}$ measured urinary prednisolone 
metabolites and suggested that $0 \cdot 1-4^{\circ}$ of the dose was excreted but they were unable to distinguish between prednisolone and its metabolites. Investigation ${ }^{9}{ }^{13}$ of the excretion of ${ }^{14} \mathrm{C}$-labelled prednisolone or prednisone administered per rectum showed that much of the radioactivity appeared ${ }^{913}$ in the urine.

There has been no published comparison of the therapeutic efficacy in colitis of prednisolone administered in equal doses by mouth and by enema. A controlled therapeutic trial ${ }^{14}$ showed only that $40 \mathrm{mg}$ of prednisolone given per rectum was more effective in acute colitis than $20 \mathrm{mg}$ given by mouth. ${ }^{14}$

Prednisolone probably does exert a local effect because patients are seen in whom an enema of inadequate volume successfully treats the distal colon, but proximal inflammation persists. ${ }^{7}$ Our results suggest that prednisolone in a dose of $20 \mathrm{mg}$ by retention enema may also exert a systemic effect.

We acknowledge the practical help given by Mrs Wendy May, SRN, during the study.

\section{References}

${ }^{1}$ Matts, S G F, Lancet, 1960, 1, 517.

${ }^{2}$ English, J, Chakraborty, J, and Marks, V, Annals of Clinical Biochemistry, 1974, $11,11$.

${ }^{3}$ Colburn, W A, and Buller, R H, Steroids, 1973, 21, 833.

4 Wilson, C G, et al, British fournal of Clinical Pharmacology, 1975, 2, 321.

${ }^{5}$ Pegg, P J, and Keene, P M, Steroids, 1969, 14, 705.

6 Baron, J H, Connell, A M, and Lennard-Jones, J E, British Medical fournal, 1964, $1,89$.

${ }^{7}$ Swarbrick, E T, Loose, H, and Lennard-Jones, J E, Proceedings of the Royal Society of Medicine, 1974, 67, 753.

${ }^{8}$ Wilson, C G, May, C S, and Paterson, J W, personal communication.

${ }^{9}$ Halvorsen, S, Myren, J, and Aakvaag, A, Scandinavian fournal of Gastroenterology, 1969, 4, 581.

${ }^{10}$ British Medical fournal, 1971, 3, 84.

11 Matts, S G F, et al, British Medical fournal, 1963, 2, 24

12 Wood, W A, Walters, G, and Matts, S G F, British Medical fournal, 1964, $2,1045$.

${ }^{13}$ Spencer, J A, Kirsner, J B, and Palmer, W L, Proceedings of the Society for Experimental Biology and Medicine, 1960, 103, 74.

14 Truelove, S C, British Medical fournal, 1960, 1, 464.

\section{Do placebos alter sleep?}

\section{KIRSTINE ADAM, LIISI ADAMSON, VLASTA BŘEZINOVÁ, IAN OSWALD}

British Medical Fournal, 1976, 1, 195-196

\section{Summary}

Deliberate suggestion that an inert capsule was a sleeping pill was found not to influence subjective ratings of sleep quality or anxiety or the electrophysiologically recorded features of sleep in 10 volunteers aged 41-62 years.

\section{Introduction}

Efforts are being made to persuade doctors to prescribe fewer sleeping pills. It is often asked whether an inert substitute might be effective through suggestion alone. Kales et al compared the effect of placebo with that of no treatment in eight young men with complaints about their sleep and found no difference in objective measurements-delay to falling asleep, duration of sleep, or distribution of sleep stages - or in subjective ratings of sleep. Hartmann et $a l,{ }^{2}{ }^{3}$ in two studies, also found no clear effects. Their proposed relationship between placebo administration and an increased amount of rapid-eye-movement (REM) sleep may have been an artefact of unbalanced design.

We here report the results of a further study in which 10 volunteers were given a placebo disguised as a sleeping pill.

\section{Patients and methods}

The 10 volunteers, six women and four men, were aged 41-62 (mean 57) years. This age and sex distribution is representative of patients who most often complain of inadequate sleep. They were asked to keep to a regular daily routine and to take no drugs or alcohol.

University Department of Psychiatry, Royal Edinburgh Hospital, Edinburgh EH10 5HF

KIRSTINE ADAM, BSC, research associate

LIISI ADAMSON, licentiate in medicine, research fellow

VLASTA BREZINOVA, MD, PHD, research psychiatrist

IAN OSWALD, MD, DSC, reader in psychiatry
The volunteers were given the following written statement: "You will be given a mild sleeping pill; it will help to make your sleep more restful without causing any hangover." An inert pink pill was given 30 minutes before lights-out on half of the recorded nights. The volunteers attended the laboratory in pairs, only one of them receiving the pill on any one night. The experiment was divided into two periods of two weeks separated by 21 weeks. During each period the volunteers attended for electrophysiological recording on eight nights, the first two serving for adaptation. Thus each person received the pill on six nights and nothing on another six nights, the order being balanced.

The electroencephalogram (EEG), eye movements, and submental muscle tone were recorded from 22.30 until 07.15 . The recordings were categorised ${ }^{4}$ by a scorer who was unaware of the experimental condition, and the sleep and wakefulness data then analysed for their mean accumulation in minutes after one hour, two hours, and so on up to seven hours of sleep.

Each evening the volunteers rated their average anxiety for the day, and each morning rated their sleep, using $10 \mathrm{~cm}$ visual analogue scales. The scales ranged from "terrible agitation" to "imperturbable tranquillity," and from "the worst" to "the best night imaginable." Correlated $t$ tests were used to compare the 60 placebo nights and 60

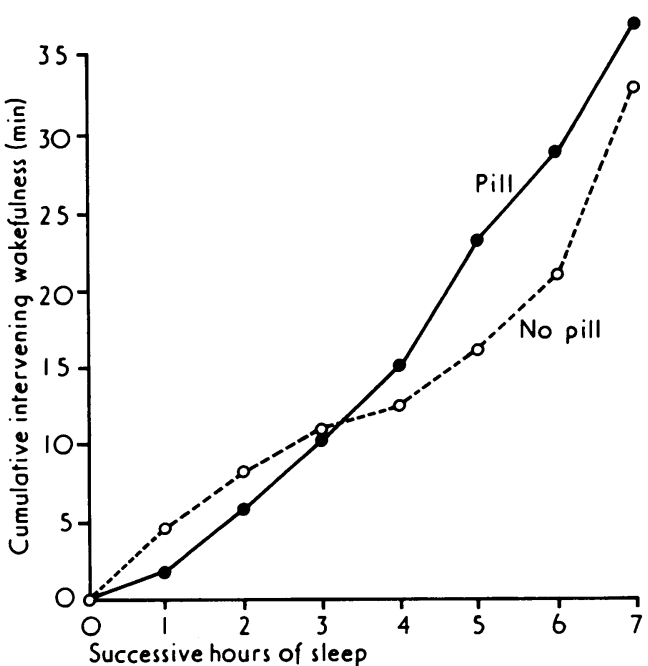

FIG 1-Mean cumulative minutes of wakefulness during night's sleep of 10 volunteers on pill nights and no-treatment nights $(t=0.90 ; \mathrm{DF}=9 ; \mathrm{NS})$. 